\title{
EDITORIAL \\ Recepción incrementada, pero baja aceptación de trabajos: un análisis de sus causas en el año que termina.
}

Termina el año 2021 e Investigación Clínica exhibe un aumento de más del 50\% en la recepción de trabajos, en comparación con el año anterior. Este incremento probablemente se deba a que nuestra revista es de fácil acceso para la recepción de contribuciones; basta con seguir las "Instrucciones para los Autores" al escribir el artículo, enviarlo en un archivo Word y una vez considerado apto para publicación, se exige un cumplimiento estricto de las normas.

Otro aspecto a considerar, es que Investiǵación Clínica acepta trabajos de diversa índole, clínica y experimental, lo que amplía el espectro de recepción. En el Comité Editorial evitamos atenernos a temas de moda, olvidando aspectos de patologías de observancia permanente. De hecho, este año los trabajos sobre la pandemia COVID-19 han copado las revistas científicas y se espera un incremento, tal vez coyuntural, de los "índices de impacto" de aquellas que hayan publicado más trabajos sobre el tema, ello debido a la cantidad de citaciones a que esta situación conduce. Investigación Clínica, en su afán de mantener su estilo amplio y diverso, no se ha dejado arrastrar por este fenómeno, consciente del peligro de bajar el índice de impacto; sin embargo, en este año hemos publicado 8 trabajos sobre el tema, incluidos los de un suplemento con contribuciones de científicos venezolanos.

Lamentablemente, el incremento de las contribuciones logrado por la Revista, también se ha traducido en un aumento en el porcentaje de trabajos rechazados, cerca- no al $60 \%$. Esto nos ha llevado a analizar las probables causas de este fenómeno y hemos encontrado algunas que pueden haber influido. Por ejemplo, la mayoría de los trabajos, a pesar de considerar un número muy importante de casos, se basan en análisis retrospectivos de hasta 10 años atrás, en los cuales la metodología utilizada no se considera idónea para el momento actual o no fue la más adecuada para el estudio clínico o experimental realizado o los resultados no tuvieron la interpretación correcta y no es posible enmendar el problema, ello aunado a falta de sustentación en los conceptos y un conocimiento muy pobre del idioma inglés. Otros aspectos negativos fueron análisis estadísticos deficientes y discusiones poco ajustadas a los resultados, con conclusiones no acordes con lo obtenido. Por último, las referencias muchas veces estaban limitadas a revistas regionales, por lo que se carecía de una discusión más universal.

Los tiempos de arbitraje y posterior publicación siguen siendo algo extensos. Ello es debido a que hemos extremado el cuidado al revisar la identidad de los autores y su actividad científica previa, así como al escoger árbitros expertos en el campo objeto de estudio con origen geográfico diverso. Además debemos confirmar que las observaciones de los árbitros fueron cumplidas a cabalidad. Por otro lado, este año hemos sido afortunados en haber agregado una buena cantidad de revisores iberoamericanos, expertos en variados campos de investigación científica, muchos de ellos provenientes de la diáspo- 
ra venezolana dispersa por el mundo, que han aceptado, generosamente, colaborar en la evaluación de los trabajos recibidos para optar a publicación. A ellos nuestro agradecimiento.

Nuestra página web se encuentra actualmente en remodelación, pero -a pesar de algunas fallas- es posible consultarla. El contenido también se puede acceder a través del repositorio de la Universidad del Zulia.

En el próximo año, con motivo del cambio de autoridades de la Revista, haremos algunas modificaciones al estilo de los trabajos; por ejemplo, para facilitar la escritura a los contribuyentes de países donde la numeración romana no es usual, las tablas tendrán numeración arábiga. Para evitar confundir las citas de las referencias (que se colocan actualmente al ras del texto) con números correspondientes a resultados de los traba- jos, dichas citas se colocarán en superíndice. Tal como lo hicimos con el doi como identificador de trabajo, ahora estaremos recomendando a los autores que coloquen su número ORCID, identificador de autor, para adaptarnos a las nuevas exigencias editoriales y solicitaremos la obligación de manifestar la responsabilidad de cada uno de los autores en la preparación del trabajo.

Finalmente, quiero reconocer el trabajo diligente y laborioso de nuestros correctores idiomáticos por la ardua tarea de completar la publicación de cada documento en forma impecable, agradecer al equipo que conforma el Comité Editorial y los Asesores Científicos por su labor y a la diseñadora gráfica por la paciencia que implica el encuadre final de cada número.

Elena Ryder 


\section{Increased reception, but low acceptance rate of papers: an analysis of the reasons at the end of the year.}

There has been an increase of more than $50 \%$ in the reception of papers in the journal Investigacion Clínica in 2021. This might be because our journal is easily accessible to receive contributions for publication, since it is just necessary that the authors follow the Instructions of submission. Once it is accepted, the paper will immediately go to final style corrections. Additionally, we aceept papers on all subjects, clinical and experimental, and we do not give priority to any subject based on the current trending topies, with a vision of getting more eitations, forgetting important pathologies of worldwide distribution and permanent observance. Unfortunately, this increase did not resulted in more accepted papers; the rate of rejection went close to $60 \%$, a fact that prompted us to analyze the possible reasons for this phenomenon. The main causes encountered were that most of the papers consisted of retrospective studies, that although considered a very important number of eases, were based on retrospective analyzes of up to 10 years ago, and whose methodologies were inadequate or dated. In some eases the interpretation of the results, based on new knowledge, were erroneous; or had deficient statistical analysis, had discussions not adjusted to the results or most references came from regional journals, so the discussions lacked universal amplitude. Peer review and acceptation lapses are still long, because we have taken extreme care reviewing the previous scientific activity of authors, choosing referees of diverse geographical origin and assuring that the author's responses were adequate to the referees considerations. Finally, I want to acknowledge the fine work of our Committee Members in charge of the language correction, the whole Editorial Committee and the Scientific Advisors for their help and to our Graphic Designer for the patience involved in the final output of each issue. 